\title{
Budo in Physical Recreation as a Form of Rapprochement to Nature
}

\author{
Grzegorz Bielec ${ }^{1,+} \mathbb{D}$, Bartosz Dziadek ${ }^{1, *,+} \mathbb{D}$, Zbigniew Borysiuk $^{2,+} \mathbb{D}$ and Wojciech J. Cynarski ${ }^{1,+} \mathbb{D}$ \\ 1 Institute of Physical Culture Sciences, Medical College of Rzeszów University, Rzeszów University, \\ 35-959 Rzeszów, Poland; gbielec@ur.edu.pl (G.B.); cynarski@ur.edu.pl (W.J.C.) \\ 2 Faculty of Physical Education and Physiotherapy, Opole University of Technology, 45-758 Opole, Poland; \\ z.borysiuk@po.opole.pl \\ * Correspondence: bdziadek@ur.edu.pl \\ + These authors contributed equally to this work.
}

check for

updates

Citation: Bielec, G.; Dziadek, B.; Borysiuk, Z.; Cynarski, W.J. Budo in Physical Recreation as a Form of Rapprochement to Nature. Sustainability 2021, 13, 6951. https://doi.org/10.3390/su13126951

Academic Editor: Gianpiero Greco

Received: 27 April 2021

Accepted: 24 May 2021

Published: 21 June 2021

Publisher's Note: MDPI stays neutral with regard to jurisdictional claims in published maps and institutional affiliations.

Copyright: (c) 2021 by the authors. Licensee MDPI, Basel, Switzerland. This article is an open access article distributed under the terms and conditions of the Creative Commons Attribution (CC BY) license (https:// creativecommons.org/licenses/by/ $4.0 /)$.
Abstract: Martial arts, or budo in Japanese, are practiced recreationally on a global scale. Is there a relation between the regular practice/training of various fighting arts and the attitude of these people towards the natural world? Does budo educate in this direction? Representatives of various fighting arts $(n=145)$ were examined using a diagnostic survey. It was found that the attitude of the respondents to nature and ecology was positive for the majority of the respondents (almost $74 \%$ ). This applied to both men and women and was not determined by the level of education. The type of martial art or combat sport practiced did not differentiate this attitude.

Keywords: recreation; martial arts; physical activity; motives; nature

\section{Introduction}

In the era of the increasing amount and importance of free time, proposals for recreational activities (i.e., activities in the area of leisure) become more and more important [1-3] We adopted the concept of "recreation" here in the following sense: "A set of behaviors carried out by an individual in his spare time" [4] (p. 15). On the other hand, "physical recreation" should be understood as "activities with the content of movement, to which a person gives himself up out of his own will, in his free time for rest, renewal of strength, pleasure and development of his own personality, and health creation" [4] (p. 17). Recreation provides people health and self-realization opportunities while in contact with nature or cultural goods. Man's physical contact with the outside world is carried out through his own corporeality and generally in accordance with culturally accepted patterns. Furthermore, "It's about physical culture or movement culture. From a different perspective, physical recreation is also a part of cultural recreation, just as physical culture is an element of general culture" [5-7]. It can be assumed that the theory of physical recreation proposed by the indicated researchers fits into the anthropological and systemic concept of tourism and recreation.

The scientific framework of the present study is completed by the General Theory of Fighting Arts (GTFA) [8-11]; i.e., the most general theoretical concept that covers various forms of martial arts, combat sports and self-defense systems. GTFA includes tourism and recreation of martial arts, being a derivative of their respective anthropology [10] (pp. 19-34). Budo (Japanese: bu —martial, stop the spear; dō-way, method) is a Japanese umbrella term for the varieties of martial arts and ways of self-improvement through self-defense practice. The anthropology of recreation and tourism-in relation to martial arts and especially their practice-explains these socio-cultural phenomena with a focus on the human being as the subject of all events. If an event in the field of martial arts tourism is combined with the physical exercise of these martial arts, it is also a combination of tourism and physical recreation. Thus, in its basic form, martial arts tourism, such as trips 
to practice martial arts, are a non-local form of recreational martial arts practice [12-15]. In this study, we leave aside competitive combat sports, however.

Research conducted so far indicates the high pro-health and educational value of outdoor recreation; i.e., physical activity in free time carried out in close contact with nature. Outdoor recreation can be done in a green area (parks) or an aquatic environment (windsurfing or other recreational sports) [16-18]. However, it is rare to study the attitudes of people practicing various fighting arts (e.g., martial arts, combat sports, and self-defense systems) towards health and nature at the same time. However, in the leisure area, it is undoubtedly a large area of recreational activity [19]. Fighting arts, as a very special form of physical culture, can serve physical education, defense training and self-defense, recreation and rehabilitation. They can also be a form of recreational sport, with competition as a mobilizing factor. Moreover, they can be a form of the wider sport of a lifetime. In particular, they provide a chance to maintain a high level of motor skills until old age [20-22].

What is the motivation for recreational fighting arts? Is there a relationship between the regular practice or training of various fighting arts (e.g., martial arts, combat sports, and selfdefense systems), and the attitude of these people towards the world of nature, environment and their own health? Does budo (or related disciplines) train in this direction? The main aim of this study was to examine the relationship between regular practice/training of various fighting arts and the attitudes of people training towards the world of nature and ecology.

\subsection{Environmental Education through Martial Arts}

Responsibility and protecting the natural environment are the ethical norms not only for tourism and the martial arts tourism [23,24]. The ethical dimension of the sustainable development also concerns the phenomenon of the martial arts recreation as a form of physical activity (PA). It is included in various Chinese, Japanese and Korean martial arts.

Budo disciplines teach you to develop inner harmony, improve harmonious social relations and live in harmony with nature [25]. For instance, teaching of karate-do contains principles, methods and tools of a sustainable approach [26]. Some martial arts schools and associations teach and educate about ecology, and some even implement appropriate forms of recreational and tourist spending of free time $[3,27,28]$. This is partly the effect of today's trend to pursue everything that is natural and healthy, including studying natural medicine, practicing healthy eating, caring for one's own body and striving toward mental balance when practicing non-competitive forms of physical culture. On the other hand, we find similar content present in the centuries-old tradition of the age of warrior cultures.

Chinese and Japanese martial arts in particular are linked to natural religions such as Shintoism and Taoism. In these traditions, a warrior should contemplate and meditate on nature, harmonize his mind and draw strength from the natural world. In particular, practice should not go against nature. Hence, the anti-consumerism of the martial arts community, which is also popular today. Self-limitation and self-discipline go hand in hand. The moral path of budo does not have to borrow ideas from the philosophy of ecologism. Generally, "the ways of martial arts as a way of non-aggression, psychophysical and moral improvement serve well the idea of ecological education. Physical health and internal harmony favor a friendly attitude towards nature, even when the philosophical and ethical justifications for respect for all creation and life are ignored" [28] (p. 56).

\subsection{Getting to Know the Self Nature of the Budo Practitioner}

The term budo is a collective term for many disciplines of Japanese martial arts. Together, they are a cultural heritage of Japan. This concept is most often translated as "martial ways" or "martial arts" [29,30]. This term is used in a similar understanding in GTFA [10]. Practicing budo is a path of improving one's humanity, cultivating noble values (butoku; Japanese: war virtues) and striving for a state of harmony. "In this state the mind and body function as a single whole" [25] (p. 301). The mind-body unification and the idea of Do (Tao) come from the philosophical Taoism. The Book of the Way and Virtue 
(Tao te Ching) [31] is the prototype of the idea of the moral Way of the Warrior. The main idea here is also to strive for a state of harmony and harmonization of opposing energies, as in the concept of Yin-Yang that is found in the Chinese martial art taijiquan. Taoism has had the greatest impact on the internal styles of Chinese kung fu called neijia (for example, various taijiquan schools) and qigong exercises. They both come from Taoist monasteries. The concepts and practices of internal energy qi (Japanese and Korean: ki), Chinese traditional medicine (acupuncture and acupressure), the principles of Chinese cuisine nutrition, fengshui (room furnishing based on Taoist principles), and others are founded within the same precepts. We find similar content, indirectly and to a lesser extent, in non-Chinese martial arts.

The influence of Taoism on the way of training and life is not limited to the adherents of Taoism. Apart from China, Chinese communities in other parts of the world and Chinese martial arts incorporate Taoist principles in various sports and recreation activities as well as conditioning training methods [32,33]. In budo, on the other hand, we find the influence of Zen and other forms of Buddhism and the Shinto religion to a greater extent. The idea of self-knowledge of a person practicing martial arts, their self-improvement and personal self-realization, arise from these sources. Meditative, psychophysical and ascetic systems were used to prepare a warrior to fight the battle with readiness to die. This is what emotional self-control originally served. Today, martial arts practitioners perform difficult tasks to obtain new technical ranks and sometimes take part in sports competitions; but most of all, practice is intended to apply to daily life. In most cases, long-term training gives practitioners sufficient clout to overcome adversity. The highest levels of mastery (8-10th degree black belt) is, at least in assumption, confirmation of the achievement of the more broadly understood, supra-technical mastery.

\subsection{Recreational Advantages of Budo: Training in the Dojo and in the Field}

In today's budo, horse riding and life-and-death fighting are not typically practiced, except for the old kyubajutsu (horse archery) skills and the yabusame ritual. However, for many peoples of Asia and Europe, horseback fighting has been a special tradition for centuries, especially for Poles. Thus, horseback riding is nowadays a kind of reference to the archetype of a horse warrior and an interesting image-related entertainment, which emphasizes social status. In the past, possessing horses distinguished knights and nobility from other classes. Thus, a descendant or follower of the Polish, German or Hungarian nobility willingly engages in this form of recreation [34,35]. Horse riding (and horse tourism) are naturally performed outside in the bosom of nature.

While combat sports may adversely affect health (e.g., injuries, risk of increased aggressiveness, etc.), non-competitive karate is very good for recreation, health and harmonization of social relations [36]. The apprentice develops his emotional self-control and matures in self-discipline. During fight training, the participants are responsible for each other. In this way, the seemingly dangerous martial arts (karate or another budo discipline) become the sport of life, but without competition. This can be done in or outside a dojo (room of training, Japanese: "place of the way").

Karate is often practiced for sport but also for health or other purposes [37-39]. The same holds true for other East Asian martial arts. They are popular inter alia, because of the wealth of recreational and health-promoting values [33,40,41]. Gichin Funakoshi, considered the creator of the karate-do idea, was an opponent of sports competition. Throughout his life, he practiced karate forms, known as kata in Japanese. He recommended his students to exercise in this way, and instead of confronting an opponent; for example, to maintain the position of a rider (kiba-dachi) during a gale [42]. Practicing technical forms improves spatial orientation, motor memory, and motor coordination skills. Done repeatedly, it is a way to improve the endurance and efficiency of the body. This includes karate, taekwondo, and other similar martial arts. Research confirms that this type of training strengthens the heart and improves the overall efficiency of the body $[43,44]$. Like Funakoshi, Peter K. Jahnke was an opponent of sports karate. He regarded sports 
competition as a distortion of this martial art. He created the Zendo Karate Tai-te-tao style, in which the main goal of the exercises is personal self-creation [45]. The goal and side effect are self-defense skills practiced at a good level.

While various martial arts improve physical fitness, or rather psycho-physical activities, some practitioners also benefit from practical skills, such as safe falling, self-defense and fighting. However, because middle-aged and elderly people are reluctant to fall to the mat, forms of recreation with classical cold steel are gaining popularity [46]. It is even more attractive because it is practicing a fragment of a samurai cultural tradition that is popular in mass culture. The use of traditional weapons furthermore develops a sense of distance and extends the feeling of control to the weapon as an extension of the body, an experience not unlike what is experienced while driving a car.

The recreational values of various martial arts (both those that use hand-to-hand combat techniques and wielding weapons) add up or multiply via the synergy effect to a complete system. One such system is Takeda-ryu sobudo, and another is Idokan budo [47]. Various budo disciplines are practiced within a coherent system. Their educational systems include skills and knowledge about fighting at various distances with the use of one's own body (karate, jujutsu) and with several traditional weapons. The year-round training in the dojo is complemented by a summer camp with training in the field [48-50]. These and similar summer martial arts camps fit into the concept of ecology of scenery / landscape $[17,51,52]$. Morning meditation on a seaside beach is similar to searching for a state of harmony in its three dimensions (i.e., internal, interpersonal and in relation to the natural world).

The advantages of recreational martial arts practice include the following proenvironmental advantages:

- There is no need for a special surface/space (such as a pitch or court) or training equipment that could pollute the environment if produced;

- The body's own body is a burden, and in the advanced stage, the body of the exercising person becomes the trainer;

- In the Japanese tradition, you do not even need any footwear to exercise, because you practice barefoot in the gym;

- In addition, environmental education is implemented in some martial arts schools and organizations.

The martial arts tourist participates in this recreation if he has gone somewhere to practice. If the martial artist is only watching or discussing, he or she is engaging in a form of cultural tourism and recreation due to the lack of the physical exertion component typical of physical/physical recreation. Nevertheless, martial arts recreation does not have to be purely physical either.

\section{Materials and Methods}

The content presented above is the result of the two authors' more than 40 years of participant observation and from the authors' team that consists of academics who engage in martial arts practice. This knowledge from direct experience was complemented by an extensive analysis of the literature on the subject. In addition, a quantitative diagnostic survey was used. For this research, 145 people participated in the survey. The average age was $25.5 \pm 8.5$. The structure of the study group by gender, level of education, place of residence and type of martial art trained is presented in Table 1 . The respondents were predominately men $(n=109)$, people with primary education $(n=49)$ and people living with their parents $(n=74)$. By dividing the group according to the type of martial art practiced, the research covered karate, kung-fu, kickboxing, MMA, Idokan (jiujitsu and karate), taekwondo, judo and Brazilian jiujitsu athletes. The most numerous of these groups were the jiujitsu practitioners $(n=41)$. The respondents' advancement levels are presented in Table S1. 
Table 1. Characteristics of the group.

\begin{tabular}{cccccc}
\hline Feature & Feature Value & Abundance & $\begin{array}{c}\text { Cumulative } \\
\text { Number }\end{array}$ & Percentage & $\begin{array}{c}\text { Culumative } \\
\text { Percentage }\end{array}$ \\
\hline \multirow{2}{*}{ Sex } & women & 36 & 36 & 24.83 & 24.83 \\
& men & 109 & 145 & 75.17 & 100 \\
\hline \multirow{4}{*}{ Education } & basic & 49 & 49 & 33.79 & 33.79 \\
& medium & 36 & 85 & 24.83 & 58.62 \\
& higher & 21 & 106 & 14.48 & 73.10 \\
& higher $/$ master degree & 39 & 145 & 26.90 & 100 \\
\hline \multirow{5}{*}{ Place of residence } & own flat/house & 61 & 61 & 42.07 & 42.07 \\
& with parents & 74 & 135 & 51.03 & 93.10 \\
& dormitory /boarding house & 8 & 143 & 5.52 & 98.62 \\
& school boarding house & 2 & 145 & 1.38 & 100 \\
\hline & karate & 18 & 18 & 12.41 & 12.41 \\
& kung-fu & 23 & 41 & 15.86 & 28.28 \\
& kickboxing & 12 & 53 & 8.28 & 36.55 \\
& MMA & 9 & 62 & 6.21 & 42.76 \\
& Idokan & 12 & 74 & 8.28 & 51.03 \\
& taekwondo & 15 & 89 & 10.34 & 61.38 \\
& judo & 15 & 104 & 10.34 & 71.72 \\
& jiu-jitsu & 41 & 145 & 28.28 & 100 \\
\hline
\end{tabular}

A questionnaire was used to determine the impact of regular practice/training of various fighting arts on the attitudes of people training towards nature, environment and ecology. This questionnaire consisted of questions characterizing the respondents (gender, level of education, place of residence, type of martial art trained, training experience, level of advancement, frequency of training), questions concerning their motivations of undertaking martial arts training, as well as questions defining the respondents' attitude to training, attitude to their own health and nature and ecology. In the questions defining the attitude of the respondents to a given issue, a five-point Likert scale was used.

A frequency analysis was used in the preparation of the survey data, and the impact of individual qualitative variables (sex, education level, place of residence, type of martial art trained, training experience, level of advancement and training frequency) on the distribution of answers in selected survey questions was determined. When examining the influence of variables on the answers given in the survey, the $\chi^{2}$ test was used, for which the effect size was also determined [53].

All the results calculated in the course of the analysis were obtained using the statistical program Statistica 13.3 [54].

\section{Results}

Based on the collected survey data, an analysis of the distribution of responses in the sample was performed. The results of the analysis of the motivation factors among all respondents who undertake martial arts physical activity are presented in Table 2.

Table 2 shows that a large proportion of the respondents undertake martial arts training to improve their physical health. The next largest group practices martial arts to shape their own body and for self-improvement. The smallest percentage of respondents was motivated by family ambitions, recognition in the peer group and recognition of teachers or trainers. Considering the distribution of responses in particular groups (by sex, education, etc.; see Tables S2-S8) and determining the test probability value for the $\chi^{2}$ test, it was observed that the motivation to train martial arts depends on the education level of the respondents ( $p=0.004$, Table S2) and the type of martial art practiced ( $p=0.045$, Table S3). 
Table 2. General distribution of factors motivating to take up physical activity in martial arts.

\begin{tabular}{|c|c|c|c|c|}
\hline No. & Why Do You Attend Martial Arts Training & Abundance & $\begin{array}{l}\text { Participation in the } \\
\text { Whole Group [\%] }\end{array}$ & $\begin{array}{c}\text { Participation in All } \\
\text { Responses [\%] }\end{array}$ \\
\hline 1. & mastering the technique comes in handy in life & 76 & 52.41 & 7.72 \\
\hline 2. & for fun/to kill boredom & 48 & 33.10 & 4.88 \\
\hline 3. & to meet friends/acquaintances & 49 & 33.79 & 4.98 \\
\hline 4. & to make new friends & 40 & 27.59 & 4.07 \\
\hline 5. & in order to compete with the best & 62 & 42.76 & 6.30 \\
\hline 6. & to shape your own body & 114 & 78.62 & 11.59 \\
\hline 7. & for improving physical health & 121 & 83.45 & 12.30 \\
\hline 8. & I would like to become a professional athlete & 36 & 24.83 & 3.66 \\
\hline 9. & to increase self-esteem & 50 & 34.48 & 5.08 \\
\hline 10. & to increase your theoretical knowledge & 31 & 21.38 & 3.15 \\
\hline 11. & to gain recognition from the peer group/class & 13 & 8.97 & 1.32 \\
\hline 12. & to gain recognition from the teacher/trainer & 15 & 10.34 & 1.52 \\
\hline 13. & to have a "springboard" from study/work & 79 & 54.48 & 8.03 \\
\hline 14. & to reduce learning/work problems & 20 & 13.79 & 2.03 \\
\hline 15. & for self-improvement & 111 & 76.55 & 11.28 \\
\hline 16. & I would like to become a martial arts trainer in the future & 26 & 17.93 & 2.64 \\
\hline 17. & to satisfy the family's ambitions & 6 & 4.14 & 0.61 \\
\hline 18. & for self-defence & 87 & 60.00 & 8.84 \\
\hline
\end{tabular}

When analyzing the respondents' attitude to practicing or training martial arts in their free time (Table S9), it was found that $48.28 \%$ of all respondents are very willing to improve their martial arts skills. More than half of women $(66.67 \%)$ and a significant part of men (almost 70\%) expressed the will to spend their free time in this form (Table S9). It is also worth noting that approximately $25 \%$ of the respondents indicated they were not very willing and reluctant to spend their free time in this way. Additionally, based on the $\chi^{2}$ tests performed, it was found that the frequency of the answers was not affected by the factors taken into account, such as gender, education level, place of residence, type of martial art trained, training experience, level of advancement or training frequency (Tables S10-S15).

Taking into account respondents' attitude toward their own health (Tables 3 and S16), it was observed that the vast majority of respondents consider their health something important and even extremely important (approx. $70 \%$ ). Only $15 \%$ of the respondents said that health was not very important to them. The opinion about health was statistically significantly influenced by factors such as the level of education $(p=0.002$, Table 3$)$ and parental support in martial arts training ( $p=0.015$, Table S16). Taking into account the level of education of the respondents, health is of great importance to the group of people with primary education (approx. 28\%) and higher master's degree (over 21\%). Additionally, when assessing the attitude of the respondents to health and parents' support in martial arts training (Table S16), it was observed that about $70 \%$ of people receiving support from their relatives stated that health is at least important to them (including the $41 \%$ who said it was most important). In the case of the remaining factors, the analysis did not show their influence on the distribution of answers to this question $(p>0.05$, Tables S17-S21).

Table 3. The respondents' attitude to their own health in relation to the level of education.

\begin{tabular}{ccccccc}
\hline $\begin{array}{c}\text { Education } \\
\boldsymbol{p}=\mathbf{0 . 0 0 2}{ }^{*}(\mathbf{e s}=\mathbf{0 . 1 3})\end{array}$ & $\mathbf{1}$ & $\mathbf{2}$ & $\mathbf{3}$ & $\mathbf{4}$ & $\mathbf{5}$ & Total $^{+}$ \\
\hline basic $^{\diamond}$ & $25(51.02)$ & $16(32.65)$ & $2(4.08)$ & $4(8.16)$ & $2(4.08)$ & $49(33.79)$ \\
medium $^{\diamond}$ & $11(30.56)$ & $13(36.11)$ & $9(25.00)$ & $1(2.78)$ & $2(5.56)$ & $36(24.83)$ \\
higher $^{\diamond}$ & $3(14.29)$ & $7(33.33)$ & $3(14.29)$ & $2(9.52)$ & $6(28.57)$ & $21(14.48)$ \\
higher $_{\text {master degree }}$ mast $^{\dagger}$ & $19(48.72)$ & $12(30.77)$ & $3(7.69)$ & $4(10.26)$ & $1(2.56)$ & $39(26.90)$ \\
\hline Total $^{+}$ & $58(40.00)$ & $48(33.10)$ & $17(11.72)$ & $11(7.59)$ & $11(7.59)$ & $145(100)$ \\
\hline
\end{tabular}

Data are expressed as: ${ }^{+} \mathrm{n}$ (\% of all responses), $\diamond \mathrm{n}$ (\% in a given group); es—effect size, ${ }^{*}$ statistical significance; 1 -health is the most important for me, 2-important, 3-indifferent, 4-not very important, 5-completely unimportant. 
In the question characterizing the attitude of the respondents to nature, nature and ecology, a significant part of the respondents (nearly 74\%) seriously approached the abovementioned issues (Tables 4 and 5). Both women and men (Table 4) have a positive attitude towards ecology and the environment (approx. $67 \%$ of women, $76 \%$ of men). This is similar also in the group of people with primary education $(80 \%)$ and higher education $(87 \%$, Table 5). Moreover, no significant influence of any factor in the analyzed questions was demonstrated ( $p>0.05$, Tables S22-S26). There is no correlation between the type of martial art practiced and the attitude towards nature, nor between the level of proficiency (kyu/dan (color/black belt rank) or equivalent) and attitude towards the natural world.

Table 4. The respondents' attitude to nature and ecology among women and men.

\begin{tabular}{ccccccc}
\hline $\begin{array}{c}\text { Sex } \\
\boldsymbol{p}=\mathbf{0 . 8 2 3}(\mathrm{es}=\mathbf{0 . 0 5})\end{array}$ & $\mathbf{1}$ & $\mathbf{2}$ & $\mathbf{3}$ & $\mathbf{4}$ & $\mathbf{5}$ & Total $^{\boldsymbol{\dagger}}$ \\
\hline Woman $^{\diamond}$ & $11(30.56)$ & $13(36.11)$ & $7(19.44)$ & $4(11.11)$ & $1(2.78)$ & $36(24.83)$ \\
Man $^{\diamond}$ & $42(38.53)$ & $41(37.61)$ & $14(12.84)$ & $10(9.17)$ & $2(1.83)$ & $109(75.17)$ \\
\hline Total $^{\dagger}$ & $53(36.55)$ & $54(37.24)$ & $21(14.48)$ & $14(9.66)$ & $3(2.07)$ & $145(100)$ \\
\hline
\end{tabular}

Data are expressed as: ${ }^{\dagger} \mathrm{n}$ (\% of all responses), $\diamond \mathrm{n}$ (\% in a given group); es-effect size; 1 -attitude to nature and ecology is very important for me, 2-important, 3-indifferent, 4-not very important, 5-completely unimportant.

Table 5. Respondents' attitude to nature and ecology taking into account the level of education.

\begin{tabular}{|c|c|c|c|c|c|c|}
\hline $\begin{array}{c}\text { Education } \\
p=0.079(\mathrm{es}=0.11)\end{array}$ & 1 & 2 & 3 & 4 & 5 & Total $^{\dagger}$ \\
\hline basic $^{\diamond}$ & $20(40.82)$ & $19(38.78)$ & $6(12.24)$ & $3(6.12)$ & $1(2.04)$ & $49(33.79)$ \\
\hline medium $\diamond$ & $9(25.00)$ & $15(41.67)$ & $6(16.67)$ & $5(13.89)$ & $1(2.78)$ & $36(24.83)$ \\
\hline higher $\diamond$ & $3(14.29)$ & $7(33.33)$ & $5(23.81)$ & $5(23.81)$ & $1(4.76)$ & $21(14.48)$ \\
\hline higher/master degree ${ }^{\diamond}$ & $21(53.85)$ & $13(33.33)$ & $4(10.26)$ & $1(2.56)$ & - & $39(26.90)$ \\
\hline Total $^{+}$ & $53(36.55)$ & $54(37.24)$ & $21(14.48)$ & $14(9.66)$ & $3(2.07)$ & $145(100)$ \\
\hline
\end{tabular}

Data are expressed as: ${ }^{\dagger} \mathrm{n}$ (\% of all responses), $\diamond \mathrm{n}$ (\% in a given group); es-effect size; 1 -attitude to nature and ecology is very important for me, 2-important, 3-indifferent, 4-not very important, 5-completely unimportant.

\section{Discussion}

Sustainable physical recreation—through martial arts—serves people well, realizing numerous values. An example is IPA, Idokan Poland Association [47], an organization operating for almost 30 years. Instructors in clubs, as well as animators of recreation in hotels, have the task of motivating the charges to act [55]. In addition, these activities should be pro-health and pro-environmental.

It is difficult to overestimate the importance of various forms of outdoor activities and green education for leisure and recreational physical activity as well as health $[17,19]$. Martial arts recreation and martial arts tourism can be considered outdoor physical activities (PA). There are "specifically: (a) physically oriented tourism, (b) tourism that uses PA to increase comfort, attractiveness, and well-being, and (c) tourism that uses PA for health benefits" $[26,56]$.

In the studies of sports wushu and taekwondo practitioners, a moderate health orientation was found [57-59]. The results of other international studies showed that the level of education of the respondents, cultural background and health choices were not related to the respondents practicing various types of fighting arts (martial arts, combat sports, combat systems) [60]. Sometimes the emphasis on health and ecology is stronger, but it may result from the age of the studied community [21,46] or the "Taoist view" of such exercises $[33,39]$. Yang style taijiquan and various types of qigong are, for instance, practiced primarily for health.

Indeed, the ancient Greek idea of kalokagathia to pursue harmonious psychophysical development through exercise is realized not only in aikido [61] but in many varieties of 
martial arts. Educational systems such as Idokan (Idokan Yoshin-ryu budo) provide health and environmental education. Idokan promotes the ecological philosophy of the way of martial arts and anti-consumerism, health education according to the systemic theory of health, prevention (dietary and hygienic recommendations) and the transfer of appropriate knowledge $[3,28]$. Traditional Chinese martial arts, known as wushu kung-fu, function similarly $[33,62]$.

In a study conducted in one Polish voivodship for 150 respondents: "The respondents emphasized that martial arts have a significant impact on mental health and in shaping the character traits of young people. According to the respondents, practicing martial arts increases the level of physical fitness of children and adolescents, and teaches elements of self-defence. Gender significantly differentiates martial arts assessments (...) Karate is the most popular martial art among the subjects" [44]. Here, however, there was no question about the attitude towards the natural world.

In another study, exercising (aikido and capoeira) and not exercising people were asked about health-related behaviors. The level of declared health-related behaviors and practices expressed with HRB indicator was statistically higher $(p=0.002)$ for persons training martial arts (81.76) than for non-practitioners (74.61). Essential differences $(p<0.05)$ were noted besides in the category of nutritional habits and health practices. A regular training of martial arts had an influence on general health-related behaviors. Active persons were more often aware, among other things, of proper nutrition habits. This proved the intellectualization of the process of health training and the transfer of desirable behaviors into everyday life [41].

In judo research, it was stated that "recreational athletes more often indicated experiencing amotivation. The intrinsic motivation to accomplish and intrinsic motivation to know turned out to be more important for athletes in training for more than 10 years, while amotivation was more often indicated to be experienced by judokas practicing judo for less than 10 years. Respondents who reported high internal motivation values and had a motivational structure they shaped themselves had been training for longer-for more than 10 years. In our study, the three motivational groups of judokas were identified, and we found that judo experience differentiated belonging to groups" [63]. Perhaps maturity is the factor that determines the attitude to health, the environment and life among people practicing combat sports (with sports competition) and martial arts recreationally. However, it is, like life's "wisdom", difficult to investigate. Regardless of this, recreational judo turns out to serve its recreational purposes better than some other forms of leisure activity [64].

Despite the fact that data for this study were particularly difficult to collect due to the COVID-19 pandemic forcing partial closures of many martial arts and combat sports institutions, a wide spectrum of different types of fighting arts was surveyed. Intuition in the field of pro-ecological and pro-environmental attitudes of people practicing budo and related fighting arts was confirmed. Apart from the main motives of exercise, such as improving health, physical fitness and personal improvement (self-realization), the indication of a positive attitude towards nature and the natural environment was particularly interesting since it was a novelty in this research.

The limitations of this study were the inclusion of representatives of only selected fighting arts and the respondents coming from only one country. Subsequent studies carried out in other schools of these or other martial arts styles and disciplines of combat sports as well as in other countries would allow to formulate more categorical general conclusions.

\section{Conclusions}

The significance of the present study is that the attitude of the respondents to nature, nature and ecology was positive for most of the respondents (almost 74\%). This applied to both men and women and was not determined by the level of education or the type of martial art. People therefore practice budo and related fighting arts to get closer to nature. Perhaps, they become more open to both people and the environment, an attitude that 
results from a sense of strength and courage. However, this is a new hypothesis, yet to be tested.

Supplementary Materials: The following are available at https://www.mdpi.com/article/10.3390/ su13126951/s1.

Author Contributions: Conceptualization, W.J.C. and Z.B.; methodology, W.J.C. and B.D.; validation, W.J.C., Z.B. and G.B.; formal analysis, B.D.; investigation, G.B.; resources, W.J.C.; data curation, B.D.; writing—original draft preparation, W.J.C.; writing—review and editing, B.D.; visualization, B.D.; supervision, W.J.C.; project administration, W.J.C. and G.B.; funding acquisition, W.J.C. All authors have read and agreed to the published version of the manuscript.

Funding: This research received no external funding.

Institutional Review Board Statement: The study was conducted according to the guidelines of the Declaration of Helsinki, and approved by the Ethics Committee of the University of Rzeszów (approval no. 3 November 2017).

Informed Consent Statement: Informed consent was obtained from all subjects involved in the study.

Data Availability Statement: The authors confirm that the data supporting the findings of this study are available within the article and its supplementary materials.

Conflicts of Interest: The authors declare no conflict of interest.

\section{References}

1. Pieper, J. Leisure: The Basis of Culture; Ignatius Press: San Francisco, CA, USA, 2009.

2. Rojek, C. The Labour of Leisure: The Culture of Free Time; SAGE Publications: London, UK, 2010.

3. Cynarski, W.J.; Grzywacz, R. Tourist, ecological and recreational behaviours in leisure time-contribution to the sociology of leisure. Pr. Nauk. Akad. Jana Dtugosza Częstochowie Kult. Fiz. 2016, 15, 79-88. [CrossRef]

4. Kiełbasiewicz-Drozdowska, I. Zarys rozwoju refleksji teoretycznej nad problematyka rekreacji [Outline of the development of theoretical reflection on the issues of recreation]. In Teoria i Metodyka Rekreacji; Siwiński, W., Pluta, B., Eds.; Akademia Wychowania Fizycznego w Poznaniu: Poznań, Poland, 2010, pp. 9-27.

5. Cynarski, W.J. Spotkania, Konflikty, Dialogi-Analiza Wybranych Obszarów Kultury Fizycznej i Turystyki Kulturowej [Meetings, Conflicts, Dialogues. Analysis of Selected Areas of Physical Culture and Cultural Tourism], 2nd ed.; Rzeszow University Press: Rzeszow, Poland, 2010.

6. Cynarski, W.J.; Obodyński, K. Filozoficzna refleksja nad rekreacja-Założenia nowej antropologii [Philosophical reflection on recreation-Assumptions of a new anthropology]. In Trendy Pohybovej Rekreácie a Súčasný Životný Štýl, Univerzita P.J. Šafárika v Košiciach, Ústav Vzdelávania v Rožňave (Slovakia); Ḋuriček, M., Gallo, P., Eds.; Ústav Vzdelávania: Košice, Slovakia, 2007; pp. $14-19$.

7. Obodynski, K. Encounters, conflicts, dialogues. Analysis of selected areas of physical culture and cultural tourism (a review). Eur. J. Tour. Res. 2008, 1, 161-163.

8. Obodynski, K. Podstawy teoretyczne humanistycznej nauki o sztukach walki [Theoretical foundations of humanistic science of martial arts]. In Humanistyczna Teoria Sztuk i Sportow Walki-Koncepcje i Problem; Cynarski, W.J., Obodyński, K., Eds.; Rzeszow University Press: Rzeszow, Poland, 2003; pp. 11-16.

9. Obodyński, K. Anthropology of martial arts as a scientific perspective for research. In Martial Arts and Combat Sports-Humanistic Outlook; Cynarski, W.J., Ed.; Rzeszow University Press: Rzeszow, Poland, 2009; pp. 35-50.

10. Cynarski, W.J. Martial Arts \& Combat Sports: Towards the General Theory of Fighting Arts; Wydawnictwo Naukowe Katedra: Gdańsk, Poland, 2019.

11. Pawelec, P. Martial arts and combat sports. Towards the general theory of fighting arts: Book review. Ido Mov. Cult. J. Martial Arts Anthropol. 2020, 20, 54-57.

12. Buchhold, M. Sprawozdanie z obchodów jubileuszu 50-lecia IMAF i międzynarodowego spotkania w Japonii [Report on the 50th anniversary of the IMAF and the international meeting in Japan]. Ido Mov. Cult. 2002, 3, 298-300.

13. Cynarski, W.J. Anthropology of fighting arts-Munich, Anno Domini 2019. Ido Mov. Cult. J. Martial Arts Anthropol. 2019, $19,58-67$.

14. Johnson, J.; Cynarski, W.J.; Lee, S. Taekwon-Do in North Korea: A Pedagogical Case Study. Ido Mov. Cult. J. Martial Arts Anthropol. 2020, 20, 33-43. [CrossRef]

15. Dutt, C.S. Cynarski, W.J. (2020). Tourism of Martial Arts: Social-cultural perspective. Rzeszow: Wydawnictwo Uniwersytetu Rzeszowkiego. Eur. J. Tour. Res. 2021, 27, 2713.

16. Humberstone, B. The 'outdoor industry'as social and educational phenomena: Gender and outdoor adventure/education. J. Adventure Educ. Outdoor Learn. 2000, 1, 21-35. [CrossRef]

17. Eichberg, H. Outdoor activities, green education and landscaping. Ido Mov. Cult. 2007, 7, 132-142. 
18. Humberstone, B. Embodiment and social and environmental action in nature-based sport: Spiritual spaces. Leis. Stud. 2011, 30, 495-512. [CrossRef]

19. Kim, M.K.; Lee, D.; Kim, S.K.; Kim, M. Leisure constraints affecting experienced martial arts participants. Asia Pac. J. Tour. Res. 2015, 20, 1063-1079. [CrossRef]

20. Cynarski, W.J.; Sieber, L.; Szajna, G. Martial arts in physical culture. Ido Mov. Cult. J. Martial Arts Anthropol. 2014, 14, 31-38.

21. De Brito, A.V.; Rodríguez-Ferreira, M.A.; Cynarski, W.J.; Gutiérrez-García, C. Aging effects on neuromuscular activity in karate practitioners. J. Sport. Sci. 2015, 3, 203-213.

22. Mytskan, B.M.; Cynarski, W.J.; Fedoryuk, A.; Popel, S.L.; Mytskan, T.S.; Zemska, N.O. Correction of elderly age people's psycho-physiological condition by recreation motor activity. Pedagog. Psychol. Med. Biol. Probl. Phys. Train. Sport. 2017, 21, 41-45. [CrossRef]

23. Kazimierczak, M. Ethical dimension of the sustainable development in tourism. In Regional Tourism versus European Integration and Globalization; Obodyński, K., Cynarski, W.J., Eds.; Rzeszow University Press: Rzeszow, Poland, 2005; pp. 52-55.

24. Kazimierczak, M. The ethic codes as a chance for tourism? Ido Mov. Cult. 2006, 6, 11-20.

25. Davey, H.E. Budö and Harmony. Ido Mov. Cult. 2002, 3, 301.

26. Čapulis, S.; Dombrovskis, V.; Guseva, S. Principles, Methods and Tools of the Sustainable Approach in the Contents of Karate-Do Teaching. In Proceedings of the ICPESK 2015: 5th International Congress of Physical Education, Sports and Kinetotherapy, Bucharest, Rumania, 10-13 June 2015; pp. 30-38.

27. Cynarski, W, J.; Litwiniuk, A.; Błach, W. Ekologiczna era w organizacjach pozarządowych w Polsce na przykładzie "Asocjacji” The ecological era in non-governmental organizations in Poland on the example of "Asocjacje". Ido Mov. Cult. 2006, 6, $261-267$.

28. Sieber, L.; Litwiniuk, A.; Cynarski, W.J. Ecological education through the ways of martial arts. Ido Mov. Cult. J. Martial Arts Anthropol. 2010, 10, 553-557.

29. Sasaki, T. Budo (the martial arts) as Japanese culture: the outlook on the techniques and the outlook on the human being. In Martial Arts and Combat Sports-Humanistic Outlook; Cynarski, W.J., Ed.; Rzeszow University Press: Rzeszow, Poland, 2009; pp. $46-49$.

30. Nakiri, F. Concept of Budo and the history and activities of the Japanese Academy of Budo. Ido Mov. Cult. J. Martial Arts Anthropol. 2015, 15, 11-25.

31. Tzu, L. Droga (Trans. M. Fostowicz-Zahorski) [Tao Teh King], 1st ed.; Rękodzielnia "Arhat": Wrocław, Poland, 2001.

32. Cynarski, W.J. Ideological conditioning of martial arts training. Phys. Act. Rev. 2018, 6, 14-21. [CrossRef]

33. Fu, Y. The influence of the philosophy of traditional Chinese martial arts on the development of public health education. Indian J. Pharm. Sci. 2019, 81, S43.

34. Obodyński, K.; Cynarski, W.J. Horse-riding in the Recreation and Tourism. Int. J. East. Sport. Phys. Educ. 2006, 1, $104-113$.

35. Cynarski, W, J.; Obodyński, K. Horse-riding in the physical education, recreation and tourism-Axiological reflection. Res. Yearb. Stud. Phys. Educ. Sport 2008, 14, 37-43.

36. Cynarski, W.J.; Sieber, L.; Litwiniuk, A. Nierywalizacyjne karate w rekreacji [Non-competitive karate in recreation]. In Trendy Pohybovej Rekreácie a Súčasný Životný Štýl, Univerzita P.J. Šafárika v Košiciach, Ústav Vzdelávania v Rožňave (Slovakia); Ďuriček, M., Gallo, P., Eds.; Ústav Vzdelávania: Košice, Slovakia, 2007; pp. 53-57.

37. Jakhel, R.; Pieter, W. Changes in primary motives of karate beginners between 1970-1999. Ido Mov. Cult. J. Martial Arts Anthropol. 2013, 13, 48-57.

38. Biernat, E.; Krzepota, J.; Sadowska, D. Martial arts as a form of undertaking physical activity in leisure time analysis of factors determining participation of Poles. Int. J. Environ. Res. Public Health 2018, 15, 1989. [CrossRef] [PubMed]

39. Chang, Y.C.; Yeh, T.M.; Pai, F.Y.; Huang, T.P. Sport activity for health!! The effects of karate participants' involvement, perceived value, and leisure benefits on recommendation intention. Int. J. Environ. Res. Public Health 2018, 15, 953. [CrossRef] [PubMed]

40. Gim, J. Leisure in fighting arts: American adaptation of Eastern Martial Arts. World Leis. Recreat. 1998, 40, 11-16. [CrossRef]

41. Boguszewski, D.; Adamczyk, J.G.; Suchcicka, B.; Słyk, E.; Białoszewski, D. The estimation of health-related behaviours of men practising aikido and capoeira. Ido Mov. Cult. J. Martial Arts Anthropol. 2014, 2, 41-46.

42. Funakoshi, G. Karate-Do: My Way of Life; Kodansha International: Ohshima, Japan, 1981.

43. Bujak, Z. The health advantages of practising the patterns in taekwon-do. In Humanistyczna Teoria Sztuk i Sportów Walki. Koncepcje i Problemy; Cynarski, W.J., Obodyński, K., Eds.; Rzeszow University Press: Rzeszow, Poland, 2003; pp. 158-165.

44. Warchoł, K.; Korobeynikov, G.; Osiel, C.; Cynarski, W.J. Martial arts as a form of physical activity for children and young people in the opinion of adult inhabitants of Podkarpackie Voivodeship. Ido Mov. Cult. J. Martial Arts Anthropol. 2021, 21, $28-37$.

45. Sieber, L.; Cynarski, W.J. Peter K. Jahnke and Zendo karate Tai-te-tao. Ido Mov. Cult. 2002, 3, 257-264.

46. Cynarski, W.J.; Obodynski, K. The samurai way-Recreation with classical white weapon [in:] Z. Borysiuk. In Proceedings of the Movement and Health, 5th International Conference Proceedings, Głuchołazy, Poland, 17-18 November 2006; pp. 263-268.

47. Obodyński, K.; Cynarski, W.J. Recreational values of martial arts idōkan budō. In New Ideas in Sport Sciences: Current Issues and Perspectives, Part 2; Starosta, W., Osiński, W., Eds.; IASK: Leszno, Poland, 2003; pp. 197-200.

48. Ambroży, T. Trening Holistyczny: Wpływ Aktywności Fizycznej na Realizację Potrzeby Bezpieczeństwa Osobistego i społecznego [Holistic Training. The Impact of Physical Activity on the Fulfillment of the Needs of Personal and Social Safety]; European Association for Security: Kraków, Poland, 2005. 
49. Cynarski, W.J.; Cynarska, E. Travel to the Polish borderlands. Martial arts training and meetings on the way. Ido Mov. Cult. J. Martial Arts Anthropol. 2013, 13, 34-37.

50. Cynarski, W.J. Training trips of martial artists-Wladyslawowo '2016. Sci. Rev. Phys. Cult. 2016, 6, 184-189.

51. Naveh, Z.; Lieberman, A.S. Landscape Ecology: Theory and Application; Springer Science \& Business Media: Berlin/Heidelberg, Germany, 2013.

52. Woźniak, L.; Kuśnierz, M.; Trinks, R. The scenery-Contemporary trends of transformations and tourism. In Regional Tourism versus European Integration and Globalization; Obodyński, K., Cynarski, W.J., Eds.; Rzeszow University Press: Rzeszow, Poland, 2005; pp. 26-31.

53. Kim, H.Y. Statistical notes for clinical researchers: Chi-squared test and Fisher's exact test. Restor. Dent. Endod. 2017, 42,152 [CrossRef] [PubMed]

54. TIBCO Software Inc. Statistica (Data Analysis Software System). V. 13.0; TIBCO Software Inc.: Palo Alto, CA, USA, 2017.

55. Duricek, M.; Cynarski, W.J. Motivational incentives of allround entertainers and types of psychical processes of participants during animation programmes. Ido Mov. Cult. J. Martial Arts Anthropol. 2017, 17, 9-14.

56. Fromel, K.; Kudlacek, M.; Groffik, D. Tourism and Physical Activity Preferences: Development and Sustainability Strategy. Sustainability 2020, 12, 8824. [CrossRef]

57. Zeng, H.Z.; Cynarski, W.J.; Xie, L. Martial arts students' motivation and health related behaviours in Changshu. Ido Mov. Cult. J. Martial Arts Anthropol. 2013, 13, 72-84.

58. Zeng, H.Z.; Cynarski, W.J.; Baatz, S.; Park, S.J. Exploring Motivations of Taekwondo Athletes/Students in New York City. World J. Educ. 2015, 5, 51-63. [CrossRef]

59. Zeng, H.Z.; Cynarski, W.J. Participation Motivations of Taekwondo Athletes/Students; Lambert Academic Publishing: Saarbrücken, Germany, 2016.

60. Cynarski, W.J.; Pawelec, P.; Zeng, H.Z.; Yu, J.H.; Vit, M.; Bielec, G.; Slopecki, J.; Kubala, K.; Blazejewski, W. Social Determinants of Attitudes towards Health in Martial Arts: Comparison between combat sports and combat systems and martial arts practitioners. Ido Mov. Cult. J. Martial Arts Anthropol. 2017, 17, 23-29.

61. Reguli, Z.; Vít, M. Kalokagathia from Aikido point of view. In Martial Arts and Combat Sports—Humanistic Outlook; Cynarski, W.J., Ed.; Rzeszow University Press: Rzeszow, Poland, 2009; pp. 69-76.

62. Ying, L. New Ecology: Chinese Traditional Martial Arts Culture Protection and Carry Forward Game Analysis. Ekoloji 2019, 28, 2773-2778.

63. Malchrowicz-Mośko, E.; Zarębski, P.; Kwiatkowski, G. What Triggers Us to Be Involved in Martial Arts? Relationships between Motivations and Gender, Age and Training Experience. Sustainability 2020, 12, 6567. [CrossRef]

64. Pujszo, R.; Przybylski, G.; Pujszo, M.; Sadej, A. Recreational judo training, singing in the choir, or hip-hop dancing-The alternative opportunities to develop the human respiratory system. The pilot study. Ido Mov. Cult. J. Martial Arts Anthropol. 2015, $3,41-48$. 